\title{
The Eumedonine Genera Eumedonus H. Milne Edwards, 1834, and Gonatonotus White, 1847 (Crustacea: Brachyura: Pilumnidae) in Taiwan
}

Peter K. L Ng

Lee Kong Chian Natural History Museum, Faculty of Science, National University of Singapore, Singapore, peterng@nus.edu.sg

Chia-Wei Lin

National Museum of Marine Biology and Aquarium, Pingtung, Taiwan, y9300923@ms8.hinet.net

Follow this and additional works at: https://jmstt.ntou.edu.tw/journal

Part of the Fresh Water Studies Commons, Marine Biology Commons, Ocean Engineering Commons, Oceanography Commons, and the Other Oceanography and Atmospheric Sciences and Meteorology Commons

\section{Recommended Citation}

$\mathrm{Ng}$, Peter K. L and Lin, Chia-Wei (2021) "The Eumedonine Genera Eumedonus H. Milne Edwards, 1834, and Gonatonotus White, 1847 (Crustacea: Brachyura: Pilumnidae) in Taiwan," Journal of Marine Science and Technology. Vol. 29: Iss. 4, Article 11.

DOI: $10.51400 / 2709-6998.1592$

Available at: https://jmstt.ntou.edu.tw/journal/vol29/iss4/11

This Research Article is brought to you for free and open access by Journal of Marine Science and Technology. It has been accepted for inclusion in Journal of Marine Science and Technology by an authorized editor of Journal of Marine Science and Technology. 


\title{
The Eumedonine Genera Eumedonus H. Milne Edwards, 1834, and Gonatonotus White, 1847 (Crustacea: Brachyura: Pilumnidae) in Taiwan
}

\author{
Peter K.L. Ng ${ }^{a}$, Chia-Wei Lin ${ }^{b, c, *}$ \\ ${ }^{a}$ Lee Kong Chian Natural History Museum, Faculty of Science, National University of Singapore, 14 Science Drive 4, Singapore \\ ${ }^{\mathrm{b}}$ National Museum of Marine Biology and Aquarium, Pingtung, Taiwan \\ ${ }^{\mathrm{c}}$ Institute of Marine Biodiversity and Evolutionary Biology, National Dong Hwa University, Hualien, Taiwan
}

\begin{abstract}
Two species of eumedonine crabs, Eumedonus zebra Alcock, 1895; and Gonatonotus nasutus Chia \& Ng, 2000; are recorded from Taiwan, the former for the first time. Eumedonus is also a new genus record for the island. Notes on variation are noted and their taxonomy briefly treated. The number of eumedonine species, all of which are obligate symbionts on echinoderms, known from the island is now seven genera and seven species.
\end{abstract}

Keywords: Pilumnidae, Eumedonus, Gonatonotus, Taiwan

\section{Introduction}

$\mathrm{C}$ rabs of the pilumnid subfamily Eumedoninae Dana, 1852, are all obligate symbionts with echinoids, holothurians and crinoids (Echinodermata); and five genera and five species are currently known from Taiwanese waters [1,2]. Surprisingly, no species of Eumedonus $\mathrm{H}$. Milne Edwards, 1834, and Gonatonotus White, 1847, have been reported although members of these genera are known to occur in the Philippines and Japan. Chia \& $\mathrm{Ng}$ [3] revised the taxonomy of these two genera, clarifying the generic boundaries and species contained in each.

In this paper, we record Eumedonus zebra Alcock, 1895 [4]; and Gonatonotus nasutus Chia \& Ng, 2000 [3]; from Taiwan. The taxonomy of these species is briefly discussed and notes on their biology provided.

Specimens examined are deposited in the National Museum of Marine Biology and Aquarium
(NMMBA), Pingtung, Taiwan. Measurements (in millimetres) are of the maximum carapace width and length, respectively. The following abbreviations are used: $\mathrm{G} 1$ - male first gonopod; G2 = male second gonopod; $\mathrm{P} 2-\mathrm{P} 5$ = first to fourth ambulatory legs, respectively. The terminology used follows Davie et al. (2015).

\section{Taxonomic account}

Pilumnidae Samouelle, 1819

Eumedoninae Dana, 1852

Eumedonus H. Milne Edwards, 1834

Type species. Eumedonus niger H. Milne Edwards, 1834.

Remarks. Eumedonus species are easily distinguished from Gonatonotus primarily by the form of the ambulatory meri. In Eumedonus, the dorsal margin of the ambulatory merus (P2-P5) is always distinctly cristate whereas in Gonatonotus, it is lined with granules or tubercles but never cristate. The

Received 2 March 2020; revised 7 April 2020; accepted 30 October 2020.

Available online 3 September 2021.

* Corresponding author. National Museum of Marine Biology and Aquarium, Pingtung, Taiwan.

E-mail addresses: peterng@nus.edu.sg (P.K.L. Ng), y9300923@ms8.hinet.net (C.-W. Lin). 
length of the rostrum is not useful as a generic character and this was what partially caused the confusion between the two genera in the past [3]. Five species of Eumedonus are now recognised, with the species distinguished by the structure of the anteroexternal angle of the merus of the third maxilliped (auriculiform or rounded), whether the surfaces of the carapace and pereopods are relatively smooth or covered with strong tubercles, shape and proportions of the rostrum, and the acuity of the infraorbital tooth (sharp or blunt) ([3]: 17-18).

All Eumedonus species occur on echinoids.

Eumedonus zebra Alcock, 1895

(Fig. 1A)

Eumedonus zebra Alcock, 1895 [4]: 288 (type locality: off Sri Lanka) (for complete synonymy up to 2000, see Ref. [3]: 35); Ref. [5]: 139.

Material examined. 1 male $(13.9 \times 13.2 \mathrm{~mm})$, Kezailiao Fishing Port, Kaohsiung, Taiwan, coll. C.-W. Lin, 11 January 2014 (NMMBCD5593).

Diagnosis. Carapace pentagonal, rostrum long, tip of rostrum not deflexed; surface of carapace covered with numerous granules, some fossae. Lateral carapace teeth very sharp, tip usually directed laterally; base of tooth slender. Infraorbital tooth sharp. Subhepatic and suborbital regions strongly tuberculated. Antero-external angle of merus of third maxilliped auriculiform. Surface of male thoracic sternum highly tuberculated; median part of male thoracic sternite 4 depressed. Male telson depressed into sternopleonal cavity; surface with numerous fossae. Chelipeds granulose with scattered setae; dorsal margin of palm usually with distinct lamelliform crests in females; carpus with distinct spine on distal inner angle; median, inner proximal and outer inner part of merus each with a strong tooth, sometimes lamelliform; inner surface of basis-ischium with large tooth which may be lamelliform. Anterior margins of ambulatory merus and carpus distinctly cristate; posterior margins of merus usually with 2 distinct parallel crests; P2 dactylus not much longer than those of other legs. G1 slender, sinuous; distal bent $45^{\circ}-90^{\circ}$ (modified from Chia \& $\mathrm{Ng}$ [3]: 37).

Colour. When freshly collected, the background colour of the carapace and pereopods is dirty white with scattered blotches of brown and reddish-orange; being darker on the ambulatory legs. The median part of the dorsal carapace surface has three indistinct longitudinal reddish-orange lines with several larger red spots on the anterolateral region. The distal third of the fingers of the chela are purple; with the crests on the ambulatory legs possessing scattered short longitudinal red lines (Fig. 1A).

Remarks. The specimen agrees very well with those studied by [3]. The tip of the rostrum in the Taiwan male specimen gently is diverging outwards (Fig. 1A) but is only slightly diverging in the female type [3]: fig. 13) and straight in most specimens [3]: fig. 14). This character, however, is known to be

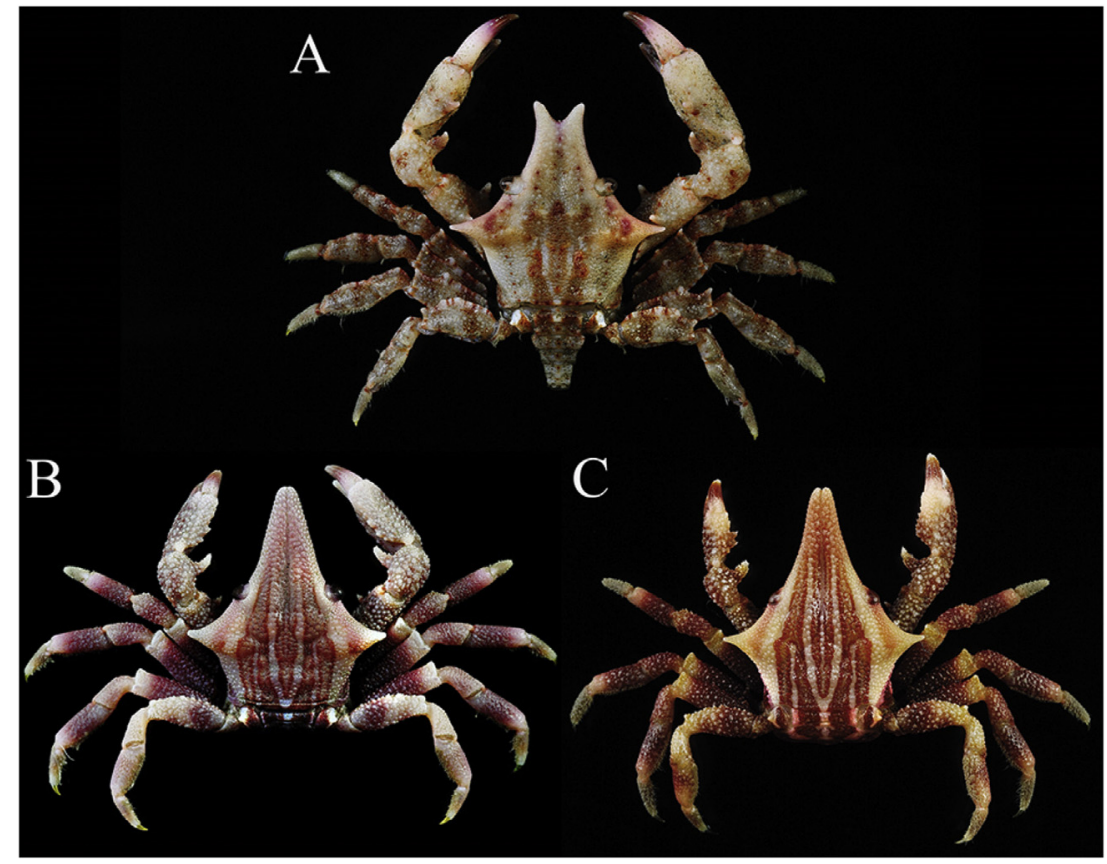

Fig. 1. Fresh colours. A, Eumedonus zebra Alcock, 1895 [4]; male $(13.9 \times 13.2$ mm), Kezailiao, Taiwan; B, Gonatonotus nasutus Chia \& Ng [3]; male $(7.9 \times 9.4 \mathrm{~mm})$ Northeast Corner, Taiwan; C, Gonatonotus nasutus Chia \& Ng [3]; female $(8.4 \times 9.6$ mm) Northeast Corner, Taiwan. 
variable in E. zebra (see [3]: fig. 15A, R, Q). In all other characters, however, the Taiwan specimen agrees with E. zebra and we have no doubt of its conspecificity.

Eumedonus zebra has a wide Indo-West Pacific distribution ranging from the Red Sea to the East China Sea, and [3] commented that its distribution overlaps with Gonatonotus granulosus (MacGilchrist, 1905) in the Indian Ocean. It would appear that it is the same for the West Pacific as both species are now also found in Taiwan.

Ecology. The specimen was collected from a fishing port off southern Taiwan, so no host data is available.

\section{Gonatonotus White, 1847}

Type species. Gonatonotus pentagonus White, 1847

Remarks. The three species of Gonatonotus can be separated by the relative length of the rostrum, proportions of the ambulatory merus, and structures of the interantennular septum and male anterior thoracic sternum ([3]: 40-41).

\section{Gonatonotus nasutus Chia \& Ng, 2000 \\ (Fig. 1B, C)}

Gonatonotus nasutus Chia \& Ng, 2000 [3]: 48, figs. 22, 23 (type locality Coral Sea) (for complete synonymy, see Refs. [3]: 48; [6]: 22); Refs. [5]: 139; [6]: 22, figs. 1-4; [7]: 4, 6, fig. 4c; [8]: 10.

Material examined. 1 male $(7.9 \times 9.4 \mathrm{~mm})$, off $82.5 \mathrm{~km}$ road marker, Northeast Corner, New Taipei City, Taiwan, coll. SCUBA, C.-W. Lin, 13 September 2014 (NMMBCD5594); 1 female $(8.4 \times 9.6 \mathrm{~mm})$, off $82.5 \mathrm{~km}$ road marker, Northeast Corner, New Taipei City, Taiwan, coll. SCUBA, C.-W. Lin, 25 June 2013 (NMMBCD5595).

Diagnosis. Carapace pentagonal, rostrum very long, length 1.1-1.3 times width; median part of ventral surface of rostrum raised; inner supraorbital teeth absent; regions well defined; surfaces of carapace, chelipeds and ambulatory legs covered with numerous tall and distinct granules; dorsal surface of carapace not setose. Antero- and posterolateral margins clearly demarcated by distinct angle or sharp tooth; anterolateral margin entire, without teeth or lobes, distinctly shorter than posterolateral margin; lateral carapace teeth very sharp, tip usually directed laterally; base of tooth stout and thick. Anterior part of interantennular septum distinctly depressed. Third maxilliped quadrate; ischium rectangular, median oblique sulcus deep; merus squarish, antero-external angle of merus not distinctly auriculiform; exopod not reaching edge of merus. Male pleon with 6 free somites and telson; telson distimnctly sunken into sternopleonal cavity. Chelipeds granulose; dorsal margin of palm with small lamelliform crests; carpus with distinct spine on distal inner angle; proximal inner, outer and median parts of merus with 2 or 3 teeth each; chela short, stout, palm length 2 times length of fingers, palm height ca 2-3 times height of fingers. Anterior margins of ambulatory merus, carpus and propodus not cristate, lined with numerous sharp, rounded granules; posterior margin of merus with low, indistinct parallel crests; P2 dactylus not much longer than those of other legs. G1 long, slightly more sinuous, distal part lined with short spines, tip bent approximately $90^{\circ}$ (Modified from Chia \& $\mathrm{Ng}$ [3]: 51).

Colour. The fresh colours of the Taiwanese G. nasutus specimens (Fig. 1B, C) agree very well with those figured and described by Endo \& Naruse ([6]: 24 , figs. 2, 5) very well and there is no need to elaborate further.

Remarks. Gonatonotus nasutus has long been confused with G. granulosus (MacGilchrist, 1905) but Chia \& Ng [3] argued that the former species has a relatively longer and more slender rostrum, the median part of ventral surface of the rostrum is raised, the anterior part of the interantennular septum is very depressed, and the tooth on the inner distal angle of the carpus of the cheliped is proportionately longer, more slender and lamelliform. Endo \& Naruse ([6]: 24) examined a series of specimens from Japan, including small ones, and commented that the relative proportions of the rostrum was still the best character to separate the two species. In addition, their distributions are separate with G. granulosus known only from the western Indian Ocean while G. nasutus occurs in Australia, New Caledonia, Vanuatu, Philippines, Japan, and now Taiwan as well.

Limviriyakul et al. [7] recorded Gonatonotus nasutus on the basis of a male collected from Prionocidaris in northern Taiwan but they did not discuss its taxonomy. In the two present Taiwan specimens, the tip of the rostrum is almost entire (Fig. 1B, C) but in the type and many of the original specimens there is a distinct median cleft ([3]: fig. 22, 23A, D). In addition, the lateral carapace spine is directed laterally (Fig. 1B, C) but is slightly curved anteriorly in the types ([3]: figs. 22, 23A, D). The material, however, agrees in all other aspects and we have no doubt that they are all conspecific.

Ecology. Most records of G. nasutus have been from sea urchins, with Endo \& Naruse [6] providing a good summary of eight or nine echinoid host species it has been found with. Noteworthy that $G$. 
nasutus has also been found with three species of holothurians, which is surprising, but these are probably not its primary hosts and may have dislodged there (see also Ref. [9]).

The two present specimens were collected from the sea urchin, Prionocidaris baculosa (Lamarck, 1816) (family Cidaridae). This sea urchin is very common in reefs in northeastern Taiwan and frequenty encountered but crabs were only found with it on this occasion. The host always come out at night and G. nasutus was found between the bases of the spines.

\section{Conflict of interest}

There is no conflict of interest.

\section{Acknowledgements}

This work is a contribution from research grants by the National Museum of Marine Biology and Aquarium, Pingtung, and the Ministry of Science and Technology, Taiwan, R.O.C.

\section{References}

[1] Ng PKL, Jeng MS. The brachyuran crabs (Crustacea: Decapoda: Eumedonidae and Portunidae) symbiotic with echinoderms in Taiwan. Zool Stud 1999;38(3):268-74.
[2] Ng PKL, Shih HT, Ho PH, Wang CH. An updated annotated checklist of branchyuran crabs from Taiwan (Crustacea: Decapoda) 2017;70(3,4):1-185.

[3] Chia DGB, Ng PKL. A revision of Eumedonus H. Milne Edwards, 1834 and Gonatonotus White, 1847 (Crustacea: Decapoda: Brachyura: Eumedonidae), two genera of crabs symbiotic with sea urchins. J Nat Hist 2000;34:15-56.

[4] Alcock A. The Brachyura Oxyrhyncha. Materials for a carcinological fauna of India, No. 1. J Asiatic Soc Bengal 1895;64(2): 157-291. pls. 3-5.

[5] Ng PKL, Guinot D, Davie PJF. Systema Brachyurorum: Part I. An annotated checklist of extant brachyuran crabs of the world. Raffles Bull Zool 2008;17(Supplement):1-286.

[6] Endo Y, Naruse T. Morphological characteristics and host species of Gonatonotus nasutus Chia \& Ng, 2000 (Crustacea: Decapoda: Brachyura: Pilumnidae: Eumedoninae) from Japan. Fauna Ryukyuana 2016;33:21-31.

[7] Limviriyakul P, Tseng L-C, Hwang J-S, Shih T-W. Anomuran and brachyuran symbiotic crabs in coastal areas between the Southern Ryukyu arc and the Coral Triangle. Zool Stud 2016; 55(7):1-14. https://doi.org/10.6620/ZS.2016.55-07.

[8] Ng PKL, Rahayu DL. A new genus and new species of pilumnid crab (Decapoda: Brachyura: Pilumnidae) symbiotic with the sponge Callyspongia Duchassaing \& Michelotti, 1864 (Porifera: Demospongiae: Callyspongiidae) from Lombok, Indonesia; the identity of Pseudactumnus pestae Balss, 1933; and a review of symbiosis in the Pilumnidae. J Crustac Biol 2020;40(6):918-32. https://doi.org/10.1093/jcbiol/ruaa042. urn:lsid:zoobank.org: pub: DB3CE3E9-46F4-492F-8B55-70DDFCFA1655.

[9] Castro P. Symbiotic Brachyura. In: Castro P, F Davie PJ, Guinot D, Schram FR, von Vaupel Klein JC, editors. Treatise on Zoology - Anatomy, Taxonomy, Biology. The Crustacea. Volume 9 Part C-I. Decapoda: Brachyura (Part 1). Leiden: Brill; 2015. p. 543-81. 